\title{
Should we test for Helicobacter pylori before treating gastroesophageal reflux disease?
}

\author{
Paul Moayyedi MD
}

\author{
P Moayyedi. Should we test for Helicobacter pylori before \\ treating gastroesophageal reflux disease? Can J Gastroenterol \\ 2005;19(7):425-427.
}

Gastroesophageal reflux disease (GERD) is a common problem in childhood. The cause is uncertain but because the incidence of GERD is increasing in developed countries and the prevalence of Helicobacter pylori is decreasing, it has been suggested that this infection protects against GERD. Observational data from 95 children, however, suggest that $H$ pylori eradication does not have a deleterious effect on GERD and this is supported by randomized controlled trials in adults. $\mathrm{H}$ pylori eradication may also reduce the efficacy of proton pump inhibitor therapy in infected patients. There are no data from children but inferences from randomized controlled trials in adults suggest this effect is likely to be modest and of uncertain clinical significance.

$H$ pylori is an important risk factor for distal gastric adenocarcinoma. It is likely that treating the infection in childhood will prevent premalignant changes associated with $H$ pylori from developing in the future. A meta-analysis of four randomized controlled trials suggest that there is a statistically significant impact on healing of chronic gastritis after one year compared with placebo (RR of chronic gastritis: $0.27 ; 95 \%$ CI 0.23 to 0.32 ). H pylori eradication is therefore recommended in children with GERD that are having an endoscopy. However, when the diagnosis of GERD is being made clinically or by $\mathrm{pH}$ monitoring, it is not necessary to screen for $\mathrm{H}$ pylori.

Key Words: Esophagitis; Gastroesophageal reflux disease; H pylori eradication; Helicobacter pylori; Proton pump inhibitor therapy

\author{
Devrait-on procéder au dépistage du \\ Helicobacter pylori avant de traiter le reflux \\ gastro-œsophagien pathologique?
}

Le reflux gastro-œsophagien pathologique (RGOP) est un trouble courant pendant l'enfance. Sa cause demeure incertaine, mais puisque l'incidence de RGOP augmente dans les pays industrialisés tandis que la prévalence du Helicobacter pylori diminue, on postule que cette infection protège contre le RGOP. Cependant, des données d'observation auprès de 95 enfants laissent supposer que l'éradication du $H$ pylori n'a pas d'effet délétère sur le RGOP, ce qui est étayé par des essais aléatoires et contrôlés chez les adultes. L'éradication du $H$ pylori pourrait également réduire l'efficacité d'un traitement aux inhibiteurs de la pompe à protons chez les patients infectés. Aucune donnée ne porte sur les enfants, mais d'après les inférences d'essais aléatoires et contrôlés chez les adultes, cet effet est probablement modeste et d'importance clinique incertaine.

Le $H$ pylori est un facteur de risque important d'adénocarcinome gastrique distal. Il est probable que le traitement de l'infection pendant l'enfance évitera que l'apparition des modifications prémalignes associées au $\mathrm{H}$ pylori plus tard. Une méta-analyse de quatre essais aléatoires et contrôlés indique la présence de répercussions statistiquement significatives de la guérison de la gastrite chronique au bout d'un an par rapport à un placebo (RR de gastrite chronique : 0,27; $95 \%$ IC 0,23 à 0,32). Par conséquent, l'éradication du $\mathrm{H}$ pylori est recommandée chez les enfants atteints de RGOP qui subissent une endoscopie. Cependant, lorsque le diagnostic de RGOP s'effectue en clinique ou au moyen d'une $\mathrm{pH}$-métrie, il n'est pas nécessaire de procéder au dépistage du $\mathrm{H}$ pylori. astroesophageal reflux disease (GERD) is a common disJorder of early infancy and symptoms occur in $6 \%$ to $8 \%$ of children aged 10 to 19 years (1). The pathophysiology of GERD is likely to be similar to adults, with transient relaxation of the lower esophageal sphincter being an important factor (2); however, asymptomatic episodes of acid reflux are more common in children (3). The incidence of GERD is rising in developed countries and it has been postulated that this could be due to the falling prevalence of Helicobacter pylori (4). There are also reports that $H$ pylori eradication reduces the efficacy of proton pump inhibitor (PPI) therapy (5). In addition, $H$ pylori infection is associated with gastric adenocarcinoma and this may be potentiated in GERD patients on long-term acid suppression (6). The present article will assume that $H$ pyloristatus testing is performed with the intention to treat the infection. The evidence for $H$ pylori eradication in GERD patients will be reviewed; specifically, in terms of exacerbating symptoms, reducing the efficacy of PPI therapy and reducing long-term complications.

\section{THE INFLUENCE OF H PYLORI ERADICATION ON GERD}

In a systematic review of 20 studies, $H$ pylori infection was less prevalent in patients with GERD compared with controls (7). This was particularly evident in Far East Asian studies. The association between $H$ pylori and GERD could be due to confounding or bias because the systematic review was based on observational data (8) and relates to all subjects, not only those that already have reflux disease.

An observational study of 95 children (9) suggested that eradication therapy did not have an impact on GERD, with reflux symptoms being similar among $H$ pylori-negative subjects and both successful and failed eradication groups (after a mean follow-up of almost one year [9]); this was additionally 


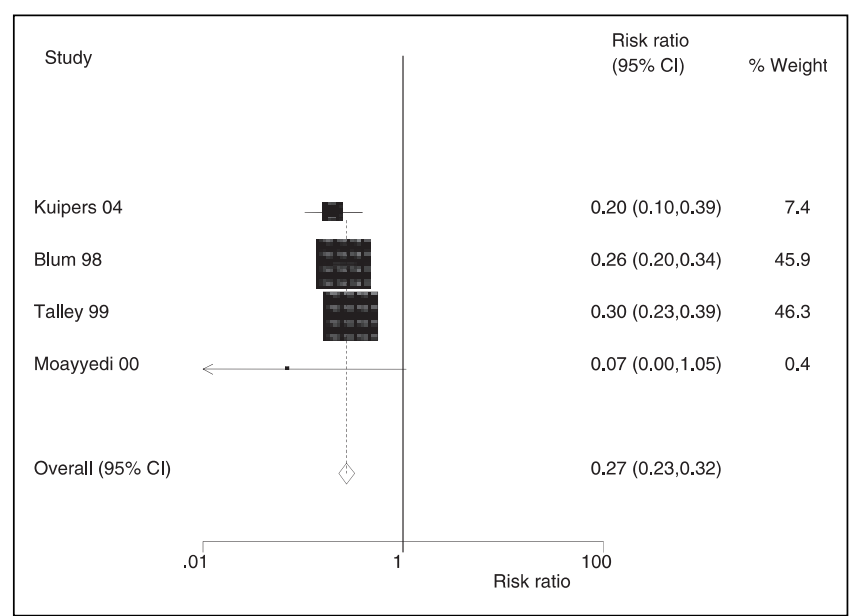

Figure 1) Randomized controlled trials reporting the efficacy of Helicobacter pylori eradication versus placebo antibiotics in chronic corpus gastritis. The outcome is a relative risk of moderate to severe gastritis versus none or mild gastritis after one year. Data from references 22, 23, 25 and 26

supported by another study (10) in 90 children. There are, however, limited data in children because the prevalence of $H$ pylori infection is low and no randomized controlled trials exist; therefore, inferences about the effects of $H$ pylori eradication in GERD need to be drawn from studies on adult patients. There are two randomized controlled trials $(11,12)$ of $H$ pylori eradication on relapse in adult GERD patients after treatment withdrawal. One trial (11) suggested that $H$ pylori reduced GERD symptoms and the other (12) reported no significant impact from $H$ pylori eradication. Overall, $H$ pylori eradication is unlikely to have a major impact on the relapse of reflux symptoms in untreated patients.

\section{THE IMPACT OF H PYLORI ERADICATION ON PPI EFFICACY}

One study (13) reported that $\mathrm{H}_{2}$-receptor antagonist therapy had similar effectiveness in both $H$ pylori-positive and -negative children with histological esophagitis; however, only 15 of 109 children were infected. PPI therapy has been shown to be the most effective pharmacological therapy for GERD in children (14); however, the impact of H pylori on PPI efficacy has not been studied in children so inferences must be made from adult data. Studies (15) have suggested that antisecretory therapy causes greater acid suppression in $H$ pylori-infected individuals; furthermore, $\mathrm{H}$ pylori eradication impairs the ability of PPI therapy to reduce acid output (16). While the area under the curve for intragastric $\mathrm{pH}$ may be significantly different in patients after $\mathrm{H}$ pylori eradication, it is unclear whether this has any clinical implications. A large study (17) in 971 patients (40\% H pylori-positive) reported that the healing of esophagitis was significantly more effective in $\mathrm{H}$ pylori-positive patients; however, there is doubt about the clinical significance of this finding because there was less than a 5\% difference between the two groups at eight weeks. That study (17) was supported by two randomized controlled trials $(18,19)$ that reported a trend for reduced healing of esophagitis in patients given $\mathrm{H}$ pylori eradication therapy.
GERD is a chronic disease and patients often need longterm therapy. The impact of $H$ pylori eradication on maintenance therapy also needs evaluation. Two randomized trials $(12,19)$ have assessed this and there was no difference in relapse rate between those receiving active and placebo antibiotics. A United Kingdom trial (12) reported an 83\% relapse rate in both groups, while a Hong Kong study (19) found that relapse occurred in 10 of 53 patients assigned to eradication therapy and eight of 51 patients given placebo antibiotics. Once the acute healing and maintenance therapy were combined in the Hong Kong trial (19), the probability of treatment failure was significantly higher in the eradication group (43\%) compared with the H pylori-positive group (21\%).

Rebound acid secretion occurs in patients given $H$ pylori eradication therapy on discontinuation of PPI therapy that persists for at least 56 days (20). This does not seem to have a major clinical impact, however, because relapse of GERD after stopping PPI therapy was similar in those randomly assigned to eradication therapy or placebo (12).

\section{THE EFFECT OF H PYLORI ERADICATION ON LONG-TERM COMPLICATIONS OF THE INFECTION}

Children with GERD that are infected with $H$ pylori will be placed on PPI therapy. Acid suppression will change the topography of infection from an antral- to a corpus-predominant disease (21). This, in turn, may lead to an increased risk of gastric atrophy and intestinal metaplasia $(6,22)$, although data are conflicting (23). What is certain, is that $H$ pylori is a major risk factor for noncardia gastric adenocarcinoma (24), and children with this infection have at least a fivefold increased risk of developing stomach neoplasia in later life. This risk is likely to be reversed with $H$ pylori eradication. There is controversy as to when the premalignant changes induced by $\mathrm{H}$ pylori become irreversible, but in children it is very likely that eradication therapy will prevent most gastric adenocarcinoma in later life. A literature search identified four randomized controlled trials $(22,23,25,26)$ with extractable data that show that anti-H pylori therapy usually returns the mucosa to normal, or with just mild inflammation, after one year (Figure 1). Although this is unlikely to benefit children immediately, in the long term their risk of complicated and uncomplicated peptic ulcer disease (27) and distal gastric cancer (28) will be reduced.

\section{CONCLUSIONS}

It is possible that $H$ pylori may cause hypochlorhydria in some cases and this will protect against GERD if the lower esophageal sphincter is weak. This is relatively rare in Western countries, but is more common in Far East Asia and, of note, the two trials $(18,19)$ that reported a possible deleterious effect of $\mathrm{H}$ pylori eradication on esophagitis were from Hong Kong. $\mathrm{H}$ pylori-induced hypochlorhydria is likely very rare in children and, therefore, eradication is unlikely to have an important impact on PPI efficacy or GERD.

When the diagnosis of GERD is being made on clinical grounds or through $\mathrm{pH}$ studies, there is no need to test for $\mathrm{H}$ pylori infection. If an endoscopy is being performed it seems sensible to test for $\mathrm{H}$ pylori and offer eradication therapy if the patient is positive. This may prevent some children from developing peptic ulcer disease and gastric cancer as adults. 


\section{REFERENCES}

1. Nelson SP, Chen EH, Syniar GM, Christoffel KK. Prevalence of symptoms of gastroesophageal reflux during childhood: A pediatric practice-based survey. Pediatric Practice Research Group. Arch Pediatr Adolesc Med 2000;154:150-4.

2. Kawahara H, Dent J, Davidson G. Mechanisms responsible for gastroesophageal reflux in children. Gastroenterology 1997;113:399-408.

3. Rudolph CD, Mazur LJ, Liptak GS, et al; North American Society for Pediatric Gastroenterology and Nutrition. Guidelines for evaluation and treatment of gastroesophageal reflux in infants and children: Recommendations of the North American Society for Pediatric Gastroenterology and Nutrition. J Pediatr Gastroenterol Nutr 2001;32(Suppl 2):S1-31.

4. el-Serag HB, Sonnenberg A. Opposing time trends of peptic ulcer and reflux disease. Gut 1998;43:327-33.

5. Labenz J, Tillenburg B, Peitz U, et al. Efficacy of omeprazole one year after cure of Helicobacter pylori infection in duodenal ulcer patients. Am J Gastroenterol 1997;92:576-81.

6. Kuipers EJ, Lundell L, Klinkenberg-Knol EC, et al. Atrophic gastritis and Helicobacter pylori infection in patients with reflux esophagitis treated with omeprazole or fundoplication. N Engl J Med 1996;334:1018-22.

7. Raghunath A, Hungin AP, Wooff D, Childs S. Prevalence of Helicobacter pylori in patients with gastro-oesophageal reflux disease: Systematic review. BMJ 2003;326:737.

8. Delaney B, Moayyedi P. Eradicating H pylori. BMJ 2004;328:1388-9.

9. Levine A, Milo T, Broide E, et al. Influence of Helicobacter pylori eradication on gastroesophageal reflux symptoms and epigastric pain in children and adolescents. Pediatrics 2004;113:54-8.

10. Gold BD. Outcomes of pediatric gastroesophageal reflux disease: In the first year of life, in childhood, and in adults ... Oh, and should we really leave Helicobacter pylori alone? J Pediatr Gastroenterol Nutr 2003;37(Suppl 1):S33-9.

11. Schwizer W, Thumshirn M, Dent J, et al. Helicobacter pylori and symptomatic relapse of gastro-oesophageal reflux disease: A randomised controlled trial. Lancet 2001;357:1738-42. (Erratum in 2001;358:1734).

12. Moayyedi P, Bardhan C, Young L, Dixon MF, Brown L, Axon AT. Helicobacter pylori eradication does not exacerbate reflux symptoms in gastroesophageal reflux disease. Gastroenterology 2001;121:1120-6.

13. Rosioru C, Glassman MS, Halata MS, Schwarz SM. Esophagitis and Helicobacter pylori in children: Incidence and therapeutic implications. Am J Gastroenterol 1993;88:510-3.

14. Gold BD. Review article: Epidemiology and management of gastrooesophageal reflux in children. Aliment Pharmacol Ther 2004;19(Suppl 1):22-7.

15. Labenz J, Tillenburg B, Peitz U, et al. Effect of curing Helicobacter pylori infection on intragastric acidity during treatment with ranitidine in patients with duodenal ulcer. Gut 1997;41:33-6.
16. Labenz J, Tillenburg B, Peitz U, et al. Helicobacter pylori augments the $\mathrm{pH}$-increasing effect of omeprazole in patients with duodenal ulcer. Gastroenterology 1996;110:725-32.

17. Holtmann G, Cain C, Malfertheiner P. Gastric Helicobacter pylori infection accelerates healing of reflux esophagitis during treatment with the proton pump inhibitor pantoprazole. Gastroenterology 1999;117:11-6.

18. Wu JC, Chan FK, Wong SK, Lee YT, Leung WK, Sung JJ. Effect of Helicobacter pylori eradication on oesophageal acid exposure in patients with reflux oesophagitis. Aliment Pharmacol Ther 2002;16:545-52.

19. Wu JC, Chan FK, Ching JY, et al. Effect of Helicobacter pylori eradication on treatment of gastro-oesophageal reflux disease: A double blind, placebo controlled, randomised trial. Gut 2004;53:174-9.

20. Gillen D, Wirz AA, McColl KE. Helicobacter pylori eradication releases prolonged increased acid secretion following omeprazole treatment. Gastroenterology 2004;126:980-8. (Erratum in 2004;127:694).

21. Logan RP, Walker MM, Misiewicz JJ, Gummett PA, Karim QN, Baron JH. Changes in the intragastric distribution of Helicobacter pylori during treatment with omeprazole. Gut 1995;36:12-6.

22. Moayyedi P, Wason C, Peacock R, et al. Changing patterns of Helicobacter pylori gastritis in long-standing acid suppression. Helicobacter 2000;5:206-14.

23. Kuipers EJ, Nelis GF, Klinkenberg-Knol EC, et al. Cure of Helicobacter pylori infection in patients with reflux oesophagitis treated with long term omeprazole reverses gastritis without exacerbation of reflux disease: Results of a randomised controlled trial. Gut 2004;53:12-20.

24. Helicobacter and Cancer Collaborative Group. Gastric cancer and Helicobacter pylori: A combined analysis of 12 case control studies nested within prospective cohorts. Gut 2001;49:347-53.

25. Blum AL, Talley NJ, O'Morain C, et al. Lack of effect of treating Helicobacter pylori infection in patients with nonulcer dyspepsia. Omeprazole plus Clarithromycin and Amoxicillin Effect One Year after Treatment (OCAY) Study Group. N Engl J Med 1998;339:1875-81.

26. Talley NJ, Janssens J, Lauritsen K, Racz I, Bolling-Sternevald E. Eradication of Helicobacter pylori in functional dyspepsia: Randomised double blind placebo controlled trial with 12 months' follow up. The Optimal Regimen Cures Helicobacter Induced Dyspepsia (ORCHID) Study Group. BMJ 1999;318:833-7.

27. Ford A, Delaney B, Forman D, Moayyedi P. Eradication therapy for peptic ulcer disease in Helicobacter pylori positive patients. Cochrane Database of Syst Rev 2003;4:CD003840. (Update in 2004;4:CD003840).

28. Wong BC, Lam SK, Wong WM, et al. Helicobacter pylori eradication to prevent gastric cancer in a high-risk region of China: A randomized controlled trial. JAMA 2004;291:187-94. 


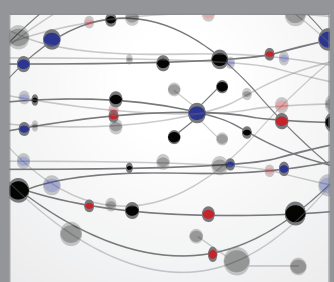

The Scientific World Journal
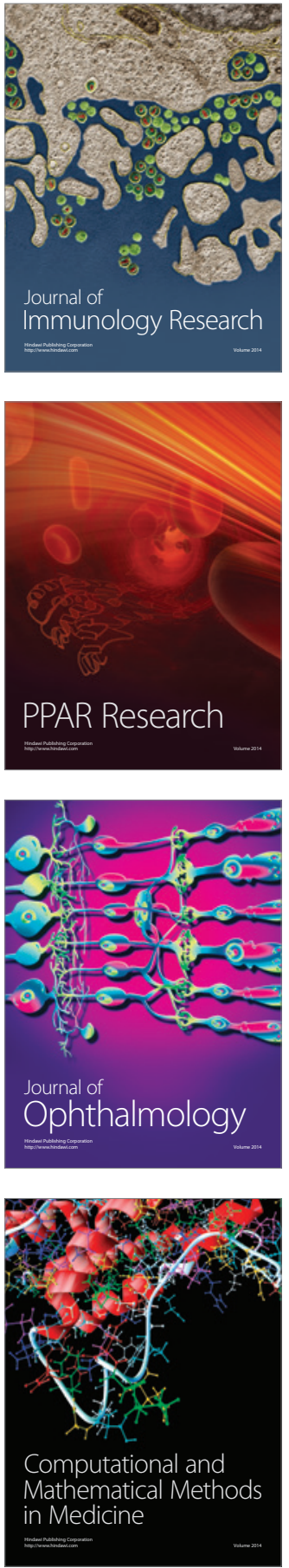

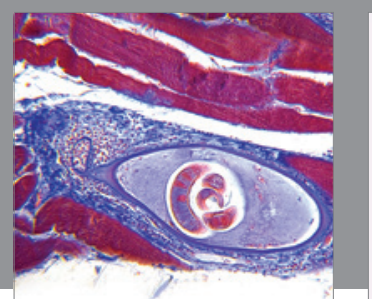

Gastroenterology Research and Practice

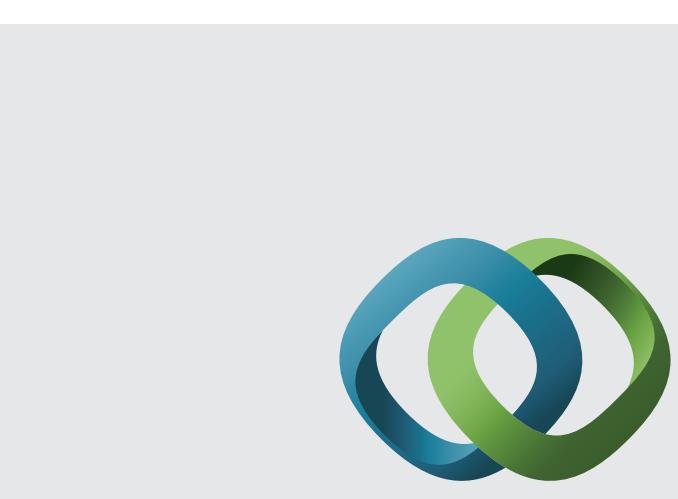

\section{Hindawi}

Submit your manuscripts at

http://www.hindawi.com
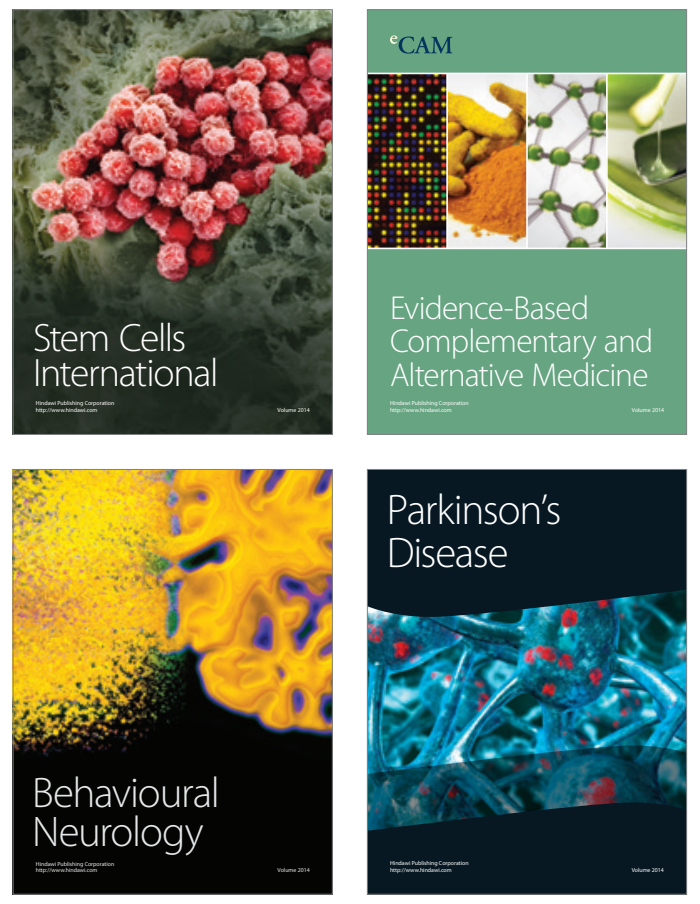
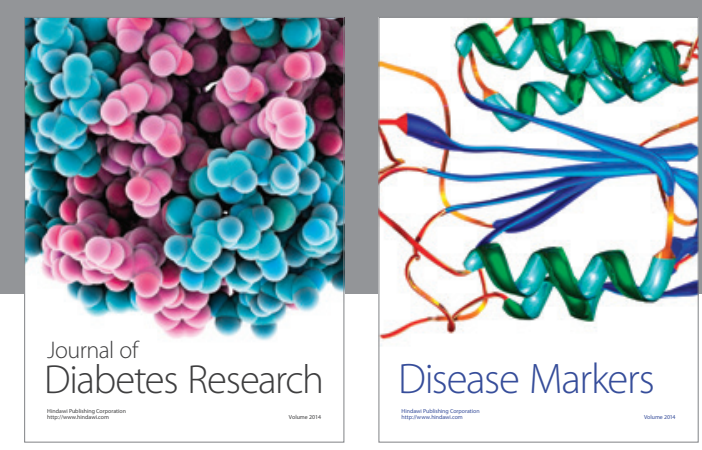

Disease Markers
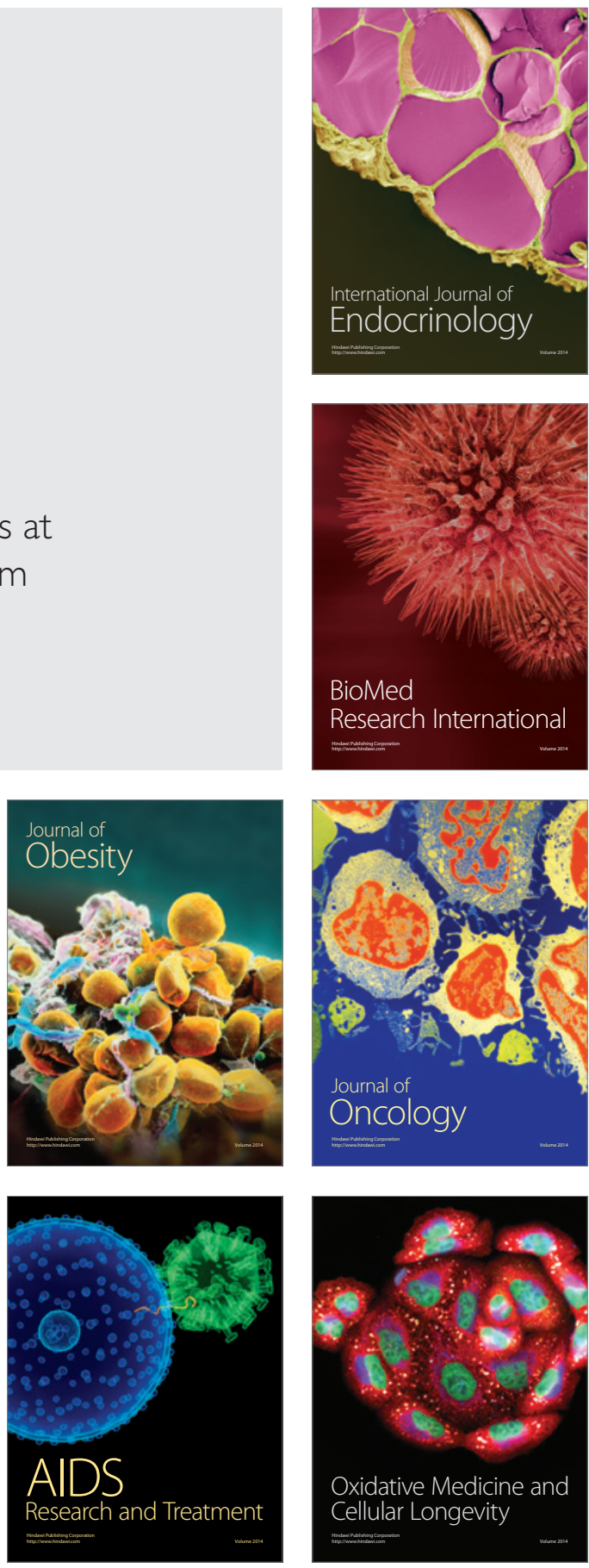